\title{
The Fair and Wise King behind the Sacred Myth of Puak Reflected the Leader Horizon Representation of Kampong Tua Malay Nongsa: Ethnoecological Approach
}

\author{
Tomi Arianto ${ }^{1}$ \\ Universitas Putera Batam, Kepulauan Riau, Indonesia \\ Tomi.arianto@puterabatam.ac.id ${ }^{l}$ \\ Melly Siska Suryani ${ }^{2}$ \\ Universitas Putera Batam, Kepulauan Riau, Indonesia \\ melly.siska@puterabatam.ac.id ${ }^{2}$
}

\begin{abstract}
Longing for a just and wise leader built a horizon of hope for society behind the mythical stories of the king of dreams. Like the fringe warriors in Javanese society, the Malays in Kampong Tua Nongsa have a role model king known as The King of Fuang. This study aimed to reveal the theme of ethnoecology in the Malay community behind the mythical story of Puak sacred in Nongsa, a Batam district. The ethnoecology approach connected a community paradigm that is formed due to natural phenomena. The interaction between humans and nature through the sacred existence of Puak was created by the role model of the king. This study used a qualitative descriptive method with observation data collection techniques and in-depth interviews. Analytical criticism techniques become a means to reveal the ethnoecology behind the story. The results of this research show that there are two important things to discuss, namely the representation of the just king and cultural products from nature in the form of prohibitions. A king whose role model serves for the hope of a community leader in the form of a king who is honest and keeps his promises, a king who does not want to be exalted and exalted, a king who is just and wise, a king who is simple, a king who protects and preserves nature. Meanwhile, the resulting cultural products are in the form of prohibitions on destroying forests, prohibitions on cutting hills, prohibitions on lying, prohibitions on speaking arrogantly, prohibitions on speaking dirty, and prohibitions on wasting wealth.
\end{abstract}

Keyword: The Sacred of Puak, Myth, Kampong Tua Nongsa, Etnoecological 


\section{INTRODUCTION}

The just and wise king who is the hope of all society until now is increasingly difficult to find. Various political promises during the campaign to be elected as leader were scattered everywhere. The public is even bored with various political promises which they forget after they have been elected. This is in line with the opinion written by Ghafur (2018) that the fundamental reason behind the emergence of community disappointment is due to election promises that never come true. People begin to realize and feel that their votes are only needed during elections, and then they are ignored when power has been achieved.

The presence myth of a fair and wise leader is not only appearing in the legend of the Pralembang Jayabaya with the presence of Ratu Adil or Satria Pingitan (Palix, 2018). The Malay community since the 12 th century AD has had the figure of a king who can bring the nation to the glory of the archipelago that can rule over the Malay plains in Singapore and Malaysia. The history began from the resident of King Isa who received a mandate from Sultan Abdul Syah until the resident of Riau to the just and simple king of Tuanku Fuan (Dahlan, 2019). This hidden myth of the king is what the Malay community continues to crave to be able to bring back the glory of
Malay in the archipelago which is increasingly eroded (Hamid, 2016).

The information regarding the existence of King Fuang tomb and his descendants was obtained by researchers from the caretaker or guardian of the Puak Sacred Temple. We got other information from the advice of the Nongsa people and native Nongsa Malays who understand the history of Tuanku Raja Fuang. The origins stories of Tuanku Raja Fuang are still very little published. His name is also less famous than other Malay kings such as Nong Isa, Raja Ali, or Raja Jaffar. However, the Nongsa Malay community believes in the myths related to the existence of Keramat Puak as a representation of King Fuang's wisdom.

The researcher in this case drew this phenomenon in ethnoecological studies to analyze the relationship between nature and interactions that affect the behavior of the surrounding community. In relation to humans and nature, Malinowski (1987) explained that humans cannot be separated from the environment in which they live, one of which is the physical environment. With that, the cultural behavior, norms, ethics of the community are related to the environment and nature that shapes it. This is also related to ethnoecological understanding. Nazarea (1999) explained that ethnoecology is a bridge to understanding human behavior 
and nature and the characteristics that shape it.

According to Hilmanto (2010), ethnoecology is understood as the mother of all scientific studies. Ethnoecology, although in its studies touches many other fields, for example: migration (sociology), traded commodities (economics), the characteristics of life for certain groups of people (anthropology), the location of longitude and latitude of an area (geography), ethnoecology actually examines the the distinctive character of a place in the broad or narrow sense inhabited by humans or society.

Regarding the data source chosen by the researchers, the interaction with the existence of the Keramat Puak myth creates people's daily behavior, including how to place them as the leader of hope. Hilmanto in Ambarwati \& Istianah (2018) explained that ethnoecology is a branch of science that examines the ways in which people use ecology and live in harmony with their natural and social environment. Thus, the behavior of the Malay Nongsa community in treating the Sacred of Puak is an ethnoecological study. This behavior is the key point in the discussion in this article.

There are two important things discussed, namely the representation of the just king and cultural products from nature in the form of prohibitions. A king who is a role model for the hope of a community leader in the form of a king who is honest and keeps his promises, a king who does not want to be exalted and exalted, a king who is just and wise, a king who is simple, a king who protects and preserves nature. Meanwhile, the resulting cultural products are in the form of prohibitions on destroying forests, prohibitions on slashing hills, prohibitions on lying, prohibitions on speaking arrogantly, prohibitions on speaking dirty and prohibition on wasting wealth.

The relationship between ethnoecological studies and literature is linked by an analysis of the myths being discussed. Oral literature is literature that includes literary expressions that are passed down and spread orally (Zaimar, 2008). Taum (2011) further explains that the main element of oral literature is aesthetics. Taum added that oral literature expresses the collective awareness of the local community (mentifact) about life, customs and beliefs. Referring to the previous concept of oral literature, it is clear that myth is an inseparable part of the study of oral literature.

\section{LITERATURE REVIEW}

\subsection{Myth as part of Oral Literature}

Oral literature is literature that includes literary expressions that are passed down and spread orally (Zaimar, 2008). Taum (2011) further explains that the main element of oral literature is aesthetics. Taum added that oral literature expresses the collective awareness of local communities (mentifact) about life, customs and beliefs. The myth itself 
according to Sarkki et al., (2018) is the disclosure and giving of identity to certain values as a sign of meaning that is believed and held firmly. Myths are conveyed through oral stories of their predecessors from generation to generation and then manifest in obedience and submission to their existence. Referring to the previous oral literary concept, it is clear that myth is an inseparable part of the study of oral literature.

\subsection{Etnoecology}

One of the studies that discussed the relationship between humans as objects and their environment is ethnoecology. Ethnoecology is a branch of science that examines the ways in which people use ecology and live in harmony with their natural and social environment. People's lives in general depend on nature so they should be closer to nature so that they can observe nature properly, observe its characteristics, and know how to manage it (Gasouka, 2017).

In this study between humans and the natural environment, an Ecological approach is used. The Ecological approach is a study that discussed and analyzed an ecological phenomenon that is focused on the relationship between humans and the natural environment. Residential areas, agriculture, urban, industrial and others are examples of ecological ecosystems that are formed from the interaction between humans and their environment (Baihaqi, 2009).

Pamela J \& Strathern (2003) seeing environment and culture are not two different things. Steward's cultural ecology theory stated that environment and culture are inseparable and both are a mixture that processes through a reciprocal relationship. If previously explained that the environment plays an important role in shaping people's culture, then in fact the culture that develops in the community also plays an important role in the sustainability of the existence of an environment. Thus the concept of ethnoecology can be used to see the meaning of society towards myths, as a form of adaptation that gives birth to their conservative attitudes towards the natural environment.

\subsection{Previous Research}

Research with the theme of ethnology in literature is in great demand by international writers but is very rare in Indonesia. The following researchers describe several references taken from the Journal and their reviews:

Research written by (Bracke, 2018) in the ISLE Journal entitled "A Man is the Story-Telling Animal: Graham Swift's Waterland". Bracke viewed that Waterland reveals eco-centrism in narrative to narrative that shapes perceptions of nature. The difference with this study is the theory used and the data sources and methods. While the equation is because it uses the object of ecology research in oral literature

Adam J. Goldwyn (2016) in the ISLE Journal indexed by Scopus raised the theme of A case study in byzantine ecocriticism: zoomorphic and anthomorphic metaphors in the Medieval 
Greek romance. Goldwyn analyzed works

of Byzantine literature from 12th century Greek romance, such as the romances of Theodore Prodromos, Rhodanthe, and Dosicles. According to him, these works often give rise to two kinds of natural metaphors: zoomorphic metaphors and anthomorphic metaphors. Contribution of thought that can be raised on the semantic meaning is in the interpretation of classical literary works.

Furthermore, the journal written by Babcock (2012) published in the $J o E$ Journal, Birgham Univeristy. Babcock discussed multi-moded measures adapted to environmental conditions / biosthetics in R. Francis's current book. This research is disclosure with the destruction of economic factors to the environment and life below the poverty line at Amherst, Massachusetts after WWII.

Previous research which also contributed to the development of this idea was written by Arianto \& Simanjuntak (2019) which raised the theme of ecology based on the story of Mak Ungkai's focal point with a feminist approach. Arianto distorted the myth of the scary image toward the spirit of Mak Ungkai became a woman who guards nature and a friend of humans. On the other hand, Arianto \& Simanjuntak (2020) added that the ecological representation of the spirit of Mak Ungkai placed humans as subjects and objects to nature. Both are interrelated and inseparable from each other.

\section{METHOD OF THE RESEARCH}

This study used a qualitative method. According to Creswell (2010), qualitative research is a method to explore and understand the meaning that by a number of individuals or groups of people ascribed social or humanitarian problems. The data collection method used observation and dept-interview techniques. The informants in this study are native Malay people in Nongsa, key keeper of the Puak sacred, community leaders, and young generation of Kampong Tua Nongsa.

The data processing of this research was carried out through the following techniques:

3.1. Listen carefully to the source of research data, both primary and secondary data that has been collected from the research location

3.2. Perform data source reduction, which is selecting data sources that are relevant to the research variable, while irrelevant data sources will be ignored.

3.3. Transcribe the recording of the interview results into phonemic form, then translate the Malay literary data into English text stories

3.4. Extract the results of observations and interview transcripts so that they become data

3.5. Re-read carefully the data that has been processed

3.6. Classifying the data with narrative approach so that the storyline units 
along with the functions and sets of stories are arranged systematically

3.7. Identifying data that has been classified with regard to the Etnoechological theory

\section{RESULT AND DISCUSSION}

The tomb of Tengku H. Fuang and his two queens are located on a plateau in Nongsa Pantai Village, Sambau Village, Nongsa. The existence of a grave complex containing 28 graves reinforces the axiom that Batam land has been inhabited by humans since the early 13th century. Some even say that starting in $231 \mathrm{AD}$ this area was crossed by the Indo-Indo Aryans. As old as the tomb of Bukit Puak, on the hill of Abdullah, Jodoh there is also a tomb which is written on the headstone in 1201 AD.

The remains historical evidence of the Kampong Tua of Malay civilization is not only leave a historical artifact but also influence the behavior of the people formed by it. The sacred of Puak or known as the tomb of Raja Tuanku Fuang is one of the historical artifacts which have a very significant influence on the lives of the Kampong Tua of Malay today. The existence of this sacred place implies a way of thinking, point of view, behavior, ethics and morals of the Kampong Tua of Malay people in various ways. Bridging the ethnoecological approach, this characterization can be traced deeper. As previously discussed, ethnoecology is a science that studies the interaction of humans and nature and how the existence of nature affects the behavior of the people in it. In this article, the researchers look at two sides; first, the existence of the sacred Puak which influences the people's perspective by making the king a role model and the hope of a leader like a role model king.

4.1. The king as the role model of community leaders

The name of Raja Tuanku Fuang and the existence of Puak Sacred or the tomb of Tuanku Fuang king is not as phenomenal as compared to his predecessor kings such as King Nong Isa with his Mediterranean mastery, Raja Abdul Jaffar with his fame, Raja Ali with his Gurindam 12. The historical artifacts of King Fuang are more isolated and not exposed to wider than the previous king. Because in essence until now the existence of his grave is more closed and not open to the public. Not everyone is allowed to visit this Tomb. Visitors must ask permission from the key guard, if allowed then visitors can visit the grave.

Although the historical artifact of Tuanku Fuang existence is closed and not opens to the public, the Malay community is very familiar with the stories of the king from his predecessors. The reflection of King Fuang characters that is described by the people of the Kampong Tua of Malay is identical to make the king's existence more grounded and becomes a role model compared to his fame. As long as the researchers have been observed and interviewed the informants, the researchers analyzed them in ethnoecological phenomenology. It is also correlated with the societies saddened by 
the presence of leaders today. Hence the existence of the king characterization as a reflection, role model and future hope for the Kampong Tua of Malay which might revive the Malay civilization back to its former glory.

\subsubsection{The king who is honest and keeps} his promises

One of the role models can be carried out from the king of Tuanku Fuang was the honesty and trust of others. Following the Prophet's Sunnah about the importance of being an honest leader and keeping promises was reflected in the king. This can be seen from the following interview excerpt:

Pusare Raje Puang merupekan zuriyat keturunan dari Raje Nong Isa, berbeza pulak dengan pusare Nong Isa, keramat Nong Isa lebih kepade secare berkeseorangan dan tidak untuk orang ramai.

Raje puang tersohor dengan kejujorannye dalam bekate, bahkan tehadap musoh nye beliau selalu menunaikan janji dan tak pernah mengingkarinye musti haros besimbah darah.

[The sacred of Puak is a zuriyat descent from Raje Nong Isa, different from the navel of Nong Isa, the sacred Nong Isa is more personal and not for the crowd. King Puang was famous for his honesty in speaking even to his enemies. He always occupies a promise and never breaks it even though he must be covered in blood.]
The quotation again provided an explanation that the Puak shrine is not too open to the public nor does it want to be flattered. But the stories about the king's character are honest and can occupy a promise that is always attached to him. Even with persistence in keeping his promise he was willing to sacrifice his body and soul. Such is the hope of the Kampong Tua of Malay for the emergence of another wise king. Not like the common leader who not only honor campaign promises but after taking his position, he has forgotten the people who voted for them.

\subsubsection{The king who doesn't want to be} exalted and exalted

Besides the existence of this tomb not for the public, the tomb of Tuanku Raja Fuang also does not want to be lavished even though he is a king like the others. The king's down-to-earth representation can also be clearly seen through the following interview excerpt:

Bile bekunjong dekat pusare Raje tuanku Fuang, kite tidak di benarkan untuk bersikap bongkak. Raje Fuang ialah Raje yang sederhane, beliau tidak ingin di tinggikan apatah lagi di dewakan. Ia jugak tidak akan meninggikan orang laen yang berimbas pade angkuh nye seseorang

[When visiting the tomb of Raja Tuanku Fuang, it is forbidden to be arrogant. King Fuang is a simple king. He does not want to be exalted and deified. He also 
will not exalt others which impact on one's arrogance.]

Apart from having permission from the key guard, the pilgrims must maintain their ethics and attitudes when visiting. It is including maintaining the attitude not to be arrogance. In essence, the act of prohibiting the arrogance of visitors is in line with the attitude of Tuanki Raja Puak himself. He is a very simple king, does not want to be exalted, nor does he want to exalt others for fear of arrogance. Likewise the existence of the sacred Puak itself, the caretaker will prohibit visitors from making this tomb as worship, let alone asking for something that is beyond God's power. During the interview, the caretaker stated that he would experience pain around the body if someone violated these provisions.

\subsection{A Simple King}

The reflection of the king's hope for a leader is like the character possessed by the king who is modest even though he is a zuriyat of a famous Malay king. This can also be seen from the interview excerpt as follows:

Kesederhaan Raje Fuang menjadikannye pribadi yg sangat di segani, tak banyak orang yang mengenal Raje Fuang secare keseluruhan. Bahkan makamnye pon di bentuk dengan secare sederhane. Beliau tidak menyukai kemewahan bile rakyatnye berade di tengah kesusahan.

[King Fuang's simplicity made him a very respected figure. Not many people know the figure of
King Fuang in detail. Even his tomb was built very simply. He does not like to be shit while his people are in trouble.]

As the quote from the interview clearly explained that the simplicity possessed by King Fuang is one of the components that he is highly respected for. In the previous explanation it was mentioned that the king of Fuang was not as famous as other Malay kings. Each Malay king has a unique leadership. Even writings specifically written about Raja Tuanku Fuang have very few references. This was also proof that this king did not want to be too deified and modest. He is present with the people and grounded with the people.

\subsection{A just and wise king}

Tuanku Tengku Fuang is the zuriyat of king Nong Isa. After being opened by Nong Isa, Nongsa slowly developed into an important port to replace the port area around the Bulang Strait which had begun to be deserted since Temenggung Abdulrahman moved to Singapore in 1818. Since 1829, Nongsa took over the function of the Bulang Strait. All ships originating from Riau (Tanjungpinang, Penyengat Island) and islands south of Bintan Island make a stop at Nongsa before crossing to Singapore. Even though his name is not as big as Raja Nong Isa, Tuanku Tengku Fuang also has an important role in the progress and development of Malay government on the coast of the Riau Archipelago. 
4.4.The existence of the King's tomb that preserved and preserved nature

One of the important studies in ethnoecology is the interaction between humans and nature which is correlated with one another. The researcher draws this case on human relations and the existence of sacred fuang in maintaining the balance of nature and protecting the environment. This is implied in the following quote:

Pantai Nongsa bersebelahan dengan resort turi golf dan wisata pantai yg laennye. Bile hendak menuju ke makam Raje fuang, Orang-orang haroslah mendaki 100 tangge. Pantang sangat bagi para pengunjong yang bersikap semena-mena macam membuang sampa semaunye sepanjang perjalanan. Jikapon memang membawa bekal yang menghasilkan sampah, bawalah sampa tu balek ketempatnye jangan rusak kesucian perjalanan dengan membuang sampah sembarang tempat.

[Nongsa Beach is close to turi resorts, golf, and other commercial beach resorts. To get to the Tomb of King Fuang, one has to climb 100 stairs. It is very abstinence for visitors who behave arbitrarily like throwing up all the way along the way. If you do bring supplies that produce trash, bring them to the place where you are not damaged by the sanctity of the trip by littering anywhere.]

The quote clearly describes how one should behave and maintain one's attitude when visiting the zuriyat grave of the Malay king. Not because he doesn't want to be disturbed, but how humans can protect and preserve nature. Never feel that the trash generated by one visitor will destroy nature. However, the carelessness of each visitor will wreak havoc on humans themselves. Both for the Malay community is around the grave and for the visitors themselves.

\subsection{Learn from the king to respect nature}

The social phenomenon is a phenomenon of human social relations. This is the most important thing in ethnoecological analysis, because the focus of the study of ethnoecology is humans who interact with nature. With the socio-anthropological knowledge of human relations, which maintains the harmony of its natural curve, it can explain the interrelation of the existence of the two relationships that are interrelated with each other. With this interaction, prohibitions emerge to limit humans destroying the harmonious relationship between nature and humans. Furthermore, this discussion will be explored from various prohibited myths originating from the existence of Raja Tuanku Fuang.

\subsubsection{Prohibition of Destroying Forests Analyzing social phenomena and the production of human and natural relations is the focus of ethnoecological studies in the socio-cultural context of society. Abstinence and forbidding Malay is a product of natural and human}


relations, especially if this taboo comes from the sacred Fuang as a representation of nature. The prohibition of destroying forests is one case raised by researchers from the myth of the prohibition of modifying graves. This can be seen from the following quote:

Jike hendak bekunjong atau teringin hendak memperbaharui pusare, harusnye bersikap ramah dan santun dengan meminta izin dahulu kepade sang pengurus pusare. Jike di perbolehkan barulah kite bise bekunjong atau pun memperbaharui pusare.

[If you want to visit or even intend to modify the tomb, you should be polite by first asking the caretaker for permission. If it is permitted, then it is permissible to visit or modify the grave.]

From quotation above, at a glance, it is not only the prohibition to modify the tomb without the permission of the key keeper but how to protect the forest and its preservation. The Puak shrine is on the top of the hill in Sambu Nongsa Village which is very strategic because it is close to a tourist attraction and has an exotic view from the top. There are many wealthy businessmen who want to invest in restoring tombs and utilizing the surrounding environment for economic values. Luckily, there is a high level of public trust in maintaining the existence of the tomb. As a result, until now the Puak tomb hill is far from being restored or modified from the hands of human capitalists.

\subsubsection{Do Not Deforest the Hill} Apart from the prohibition to develop forest around the cemetery for modifying or other purposes, The Malay's Kampung Tua Nongsa still strongly believes that cutting the Puak hill will cause havoc for the community. This is also implied in the excerpt from the interview with the key keeper.

Nature is a part of human life. One of them is the towering hills around Batam. Many of the predecessors buried their families at the top of the hill, including the zuriyat of the great king Tuanku Fuang. The Empress and her descendants are buried there. The tomb should not be moved and restored. Let it stand in a structure that blends in with nature.

\subsubsection{Prohibition to do a lie}

Ethics and morals in ethnoecological studies can also be drawn as products of nature. Ethics and morals are also created because of the continuous relationship between the two and are maintained as part of life. One of the ethics that emerges that needs to be instilled when visiting the grave is not to lie. This will be clearer from the following quotation:

Hati yang suci merupekan kunci untok dapat selamat menaiki 100 tangge bile kite berziarah di keramat puak. Minda yang burok, syak wasangke dan tipu belake menjadi hambatan bile hendak sampai ke puncak makam. Pernah ade sebuah 
kejadian, seorang pengujong yang baru saje hendak sampai ke puncak tegolek ke bawah kerana niat nye yang tak baek saat ingin memulai perjalanan

[Purity of heart is the key to surviving the 100 pilgrimage stairs to the sacred Puak. Bad thoughts, prejudice, and lies become obstacles when they are about to reach the top of the tomb. Once there was a visitor who was just about to get to the top, rolled down because of bad intentions when he started the journey.]

No one knows about matters of the heart, including lying. Therefore ethics and morals relate to each other's hearts. To guard the heart, the person himself can counter it. The belief of the Malay community about the myth of prohibiting bad thinking, prejudice and lies is an effort to protect the heart. And it is clear that the production of ethics and morals is the result of the relationship between humans and nature.

\subsubsection{Prohibition of Arrogant Words}

Another ethic that must be maintained when visiting the tomb of Raja Tuanku Fuang is the prohibition of arrogance. This can be explained through the following interview excerpt:

Bile berkunjong dilarang bersikap bongkak dan angkuh. Sikap Kuase hanye dimiliki oleh sang pencipte. Manusie hanyelah seorang hambe. Jadi sekire nye berziarah hendaklah kite merendahkan hati dan mensucikan niat terlebih dahulu.

[When visiting, it is forbidden to be arrogant and arrogant. The arrogant attitude belongs only to the creator. Man is only a servant. So if you want to go on pilgrimage, be humble and purify your intention first.]

The prohibition on being arrogant and arrogant was enforced on all visitors including key guards when they were about to go to the tomb of Raja Tuanku Fuang. This prohibition stems from humility towards God. Even King Fuang never exceeded God's power. The almighty attitude belongs only to God the creator. Whereas humans are only servants who should always approach them and humble them.

\subsubsection{Prohibition to Do Evil}

Apart from maintaining ethics and morals, many people who come to visit the graves have bad intentions to ask for help in committing crimes. This can and often happens, especially for people who are studying kanuragam or kebatinan. This was contained in a brief conversation with the caretaker:

Ada peziarah yang menyalah gunakan dengan mengambil sebagian tanah atau melakukan ritual tertentu dimakam. Hal ini terkadang menyambung dengan kegelisahan yang dialami sang 
penjaga. Perbaiki niat jika hendak berkunjung kesana

[There are pilgrims who abuse it by taking part of the land or performing certain rituals at burial. This sometimes connects with the restlessness experienced by the guard. Fix your intention if you want to visit this sacred]

While panting, the caretaker conveyed not only positive things but also negative things that often happened to the graves' visitors. Sometimes shamans or people who study mysticism come to visit the tomb of Tuanku Fuang. They even came in the middle of the night without permission from the caretaker. Even without permission, the inspiration is sometimes conveyed through dreams to the caretaker. He will experience pain and discomfort when that happens. In the context of ethnoecology, the researcher draws this as a form of maintaining ethics while visiting. Ethics do the correct intentions and not the evil.

\subsubsection{Banning the dirty words}

Oral is part of the action. Dirty speech will also bring dirty souls and it will destroy the harmonious relationship between humans and nature. In the 12 gurindam Raja Ali Haji is also mentioned Apabila perkataan yang amat kasar, lekaslah orang sekalian gusar [When said very harshly, it would make other people uncomfortable]. Not only the relationship between humans and nature, humans and the environment will become uncomfortable with these words. Even in interviews, this can be proven by the following quote:

Bile beziarah tidak di benarkan becakap yang tidak baek. Katekate maki hamun tidak di perbolehkan selame pemergian berziarah. Hal ini akan bedampak pade sumpahan bagi diri sendiri yang akan di dapati oleh pare pelawat.

[When on pilgrimage it is forbidden to say anything bad. Swear words are not permitted during a pilgrimage tour. This will create a curse of its own which the visitors will get]

No one is comfortable with harsh and dirty speech, especially if it is done in a place sanctified by everyone. It is forbidden to say harsh words, curse is strictly prohibited when visiting the grave. If in the past the myth developed that this person would become an ape and eventually become a gatekeeper for the tomb. But behind this myth, it is implied that the wisdom of the existence of this prohibition is that humans are accustomed to guarding themselves from inappropriate speech. Humans can learn to respect nature by appreciating his utters.

\subsubsection{Prohibition of wasting wealth} The King of Tuanku Fuang does not like grandeur nor does he bask in pomp. When he wanted to modify his grave, the King of Fuang, through the inspiration of the tomb guard, refused to change the structure of the original tomb. Many pilgrims who intend to modify the 
tomb with luxurious figures but are rejected through the dream will of the key keeper.

All the prohibitions and role models that have been described at length above are part of the study interestingly in the ethnoecological analysis. Ethnoecology is the study of humans and ecology as a bridge between natural and social sciences through time chronology so as to describe a particular ecological peculiarity or specification due to the forms of human interaction. The existence of Keramat Puak has very significant implications in Malay civilization, especially in Kampong Tua Nongsa. In addition to revealing the relationship between social products as a form of human interaction with nature, this article is expected to be able to open the horizons of today's modern society to be able to reap the benefits of local wisdom that still exists today.

\section{CONCLUSION}

Nusantara is rich with various ecological wisdoms and social cultures that accompanied it. Among the glitzy industrialization and the glamor of Batam city, local wisdom still exists. One of them is the existence of the king tomb of Tuanku Fuang in in Kampong Tua Nongsa. The existence of the Malay community in Batam is increasingly eliminated. Migration of people outside Batam came to try their luck looking for goodness in this industrial city. On the other hand, the Malay community, which is thick with cultural treasures, was standed firm even though it is located on the outskirts of the city. This massive migration also has an impact toward environmental and natural damage such as logging, hill trimming, and even eliminating cultural rites. The Malay community has existed since 231 AD. One of the historical evidence is the existence of the king tomb of Tuanku Fuang or known as the sacred of Puak. This sacredness then gave birth to community behavior which in ethnoecological studies was drawn as a form of human and natural interaction. The existence of this sacred place is also a symbol of civilization, culture, and society that is contained therein.

\section{REFERENCES}

Ambarwati, D., \& Istianah, F. (2018). Etnoekologi sebagai upaya membentuk karakter peduli lingkungan melalui program adiwiyata di sd negeri lidah kulon i/464 surabaya. JPGSD, 6(2).

Arianto, T., \& Simanjuntak, D. S. (2019). Paradoxical Representation of Female Narration in the Spirit of Mak Ungkai StoryNo Title. Journal BASIS, $\quad 6(2), \quad$ 173-184. https://doi.org/https://doi.org/10.338 84/basisupb.v6i2.1413

Arianto, T., \& Simanjuntak, D. S. (2020). Representation of ecocriticism in the folklore of Mak Ungkai spirit. Studies in English Language and Education, 7(2), 576-591. http://erepository.unsyiah.ac.id/SiELE/articl e/view/16822

Babcock, M. J. (2012). Biosthetics" in Robert Francis's Traveling in Concord. JOE: The Journal of Ecocriticism, 4(1), 1-19. https://ojs.unbc.ca/index.php/joe/arti cle/view/218

Baihaqi, A. (2009). Geografi. Wordpress.Com. http://baihaqiarif/files/wordpress.co $\mathrm{m}$ 
Bracke, A. (2018). Man is the StoryTelling Animal: Graham Swift's Waterland, Ecocriticism and Narratology. ISLE: Interdisciplinary Studies in Literature and EnvironmentEnvironment, 27(2), 134-146. https://doi.org/10.1093/isle/isy029

Creswell, A. J. (2010). Research design: pendekatan kualitatif, kuantitatif, dan mixed. PT Pustaka Pelajar.

Dahlan, A. (2019). HMR Kenang Jejak Historis Batam di Makam Nong Isa. Katabatamcom. https://katabatam.com/2019/12/18/h mr-kenang-jejak-historis-batam-dimakam-nong-isa/

Gasouka, M. (2017). The Importance of Feminist Ethnography in Modern Folklore Studies. International Journal of Scientific and Research Publications, 7(12), 541-544. http://www.ijsrp.org/research-paper1217/ijsrp-p7272.pdf

Goldwyn, Adam J. (2016). A Case Study in Byzantine Ecocriticism: Zoomorphic and Anthomorphic Metaphors in the Medieval Greek Romance. ISLE: Interdisciplinary Studies in Literature and Environment, 23(2), 220-239. https://doi.org/10.1093/isle/isw036

Ghafur, J. (2018). Kampanye Pemilu dan Janji Politik. FH UI. https://fh.uii.ac.id/blog/2018/12/04/k ampanye-pemilu-dan-janji-politikoleh-jamaludin-ghofur-s-h-m-h/

Hamid, A. (2016, April). Raja Isa, Sosok Penting dalam Sejarah Pemerintahan di Batam. Sindonews.Com. https://mediaindonesia.com/read/det ail/214534-jejak-historis-di-makamnong-isa

Hilmanto, R. (2010). Etnoekologi. Universitas Lampung.

Malinowski. (1987). Teori Fungsional dan Struktural," dalam Teori Antroplologi I Koentjaraningrat. Universitas Indonesia Press;

Nazarea, V. (1999). Ethnoecology: Situated Knowledge/Located Lives. The University of Arizona Press.

Palix, A. (2018, February). Kepemimpinan Hastabrata dalam Ratu Adil. Tribun. https://www.tribunnews.com/tribunn ers/2018/02/23/kepemimpinanhastabrata-dalam-ratu-adil

Pamela J, S., \& Strathern, A. (2003). Landscape, Memory and History: Anthropological Perspectives. Pluto. Press.

Sarkki, S., Heikkinen, H. I., Herva, V., \& Saarinen, J. (2018). Land Use Policy Myths on local use of natural resources and social equity of land use governance : Reindeer herding in Finland. Land Use Policy, 77(May), 322-331.

https://doi.org/10.1016/j.landusepol. 2018.05.055

Taum, Y. Y. (2011). Studi Sastra Lisan: Sejarah, Teori, Metode, dan Pendekatan Disertai Contoh Penerapannya. Lamalera.

Zaimar. (2008). Metode penelitian sastra lisan dalam metodologi kajian tradisi lisan (Ed. Pudentia MPSS). Asosiasi Tradisi Lisan. 